\title{
(Spectro)electrochemical investigations on (ferrocenyl)thiophenes modified by tungsten Fischer carbenes
}

\author{
Belinda van der Westhuizen, ${ }^{a}$ J. Matthäus Speck, ${ }^{b}$ Marcus Korb, ${ }^{b}$ Daniela I. Bezuidenhout ${ }^{a *}$ and \\ Heinrich Lang ${ }^{b^{*}}$ \\ ${ }^{a}$ Chemistry Department, University of Pretoria, Private Bag X20, Hatfield 0028, South Africa. \\ ${ }^{b}$ Technische Universität Chemnitz, Fakultät für Naturwissenschaften, Institut für Chemie, Anorganische Chemie, D- \\ 09107 Chemnitz, Germany.
}

Corresponding Authors.

Tel.: +27(0)-12-420-2626; Fax: +27-(0)12-420-4687. E-mail address: daniela.bezuidenhout@up.ac.za (D.I.

Bezuidenhout)

Tel.: +49(0)371-531-21210; fax.: +49 (0)371-531-21219. E-mail address: heinrich.lang@ chemie.tu-chemnitz.de (H. Lang)

\begin{abstract}
A series of thiophene tungsten Fischer carbene complexes of type $\left[(\mathrm{CO})_{5} \mathrm{~W}=\mathrm{C}(\mathrm{OMe}) \mathrm{R}\right](\mathbf{1}, \mathrm{R}=$ 2-Th; 3, R = fcthFc $)$ and $\left[(\mathrm{CO})_{5} \mathrm{~W}=\mathrm{C}(\mathrm{OMe})-\mathrm{R}^{\prime}-(\mathrm{OMe}) \mathrm{C}=\mathrm{W}(\mathrm{CO})_{5}\right]\left(\mathbf{2}, \mathrm{R}^{\prime}=\right.$ th; $\mathbf{5}, \mathrm{R}^{\prime}=$ fcthfc $)$ was synthesized for investigating low energy charge transfer interactions between the carbene substituents and the transition metal carbonyl fragment incorporating the thiophene heterocyclic system $(\mathrm{Th}=$ Thienyl; th $=2,5$-thiendiyl; $\mathrm{Fc}=$ ferrocenyl; $\mathrm{fc}=1,1$ '-ferrocenediyl $)$. Electrochemical investigations were carried out on these complexes to get a closer insight into the electronic properties of $\mathbf{1}, \mathbf{2}, \mathbf{4}$ and $\mathbf{5}$. They reveal reversible one-electron redox events for the
\end{abstract}


ferrocenyl moieties. Moreover, typical electrode reactions could be found for the carbene reductions itself and for the tungsten carbonyl oxidation processes. However, for the thiophene complex 2 two well-separated one-electron reduction events were observed. During the UV-VisNIR spectroelectrochemical investigations typical low energy absorptions for the mixed-valent $\alpha, \alpha^{\prime}$-diferrocenyl thiophene increment were found, as well as high energy NIR absorptions, which were attributed to metal-metal charge transfer transition between the tungsten carbonyl increment and the ferrocenyl units in the corresponding species. Further infrared spectroelectrochemical studies reveal that the electronic interactions in the corresponding cationic species can be described with weakly coupled class II systems according to Robin and Day.

Keywords:

Spectroelectrochemistry; metal-metal interaction; ferrocenyl; 2,5-diferrocenylthiophene; tungsten Fischer carbene complexes

\section{Introduction}

In recent years, the application of Fischer carbene complexes has expanded from catalysis, auxiliary ligands and application in organic chemistry to electronic probes and potential molecular wires [1]. These applications have mostly evolved around the $\mathrm{M}=\mathrm{C}$ carbene double bond but interest in the electrochemical properties of carbene complexes was the prelude to new applications, especially in the field of catalysis [2]. Fischer carbene complexes are excellent candidates for electrochemical studies as redox centers, can be extended from mono- to 
polymetallic [3], and organic or organometallic $\pi$-conjugated linkers can be used to separate transition metal moieties [4]. Combining the properties of Fischer carbenes with $\pi$-conjugated bridges could result in the design of new push-pull systems with novel non-linear optical (NLO) character. In our recent papers we paid attention to metal-metal interactions in Fischer carbenes on ferrocenyl and biferrocenyl tungsten alkylidene complexes [5]. UV-Vis-NIR spectroelectrochemical investigations revealed a high energy NIR absorption which was attributed to a metal-metal charge transfer transition (MMCT) between the tungsten and ferrocenyl/biferrocenyl moieties. Within this context, the use of redox active metal-based temini offers the possibility to design new materials, such as semiconducting polymers and molecular wires.

In this study we describe synthesis and characterization of tungsten thienyl and 2,5diferrocenylthiophenes mono- and biscarbene Fischer complexes (Scheme 1). Electrochemical and spectroelectrochemical properties were investigated.

\section{Results and Discussion}

\subsection{Synthesis and spectroscopic characterization}

The tungsten Fischer carbene complexes 1, 2, 4 and 5 were prepared employing the classical Fischer carbene synthesis: $\mathrm{W}(\mathrm{CO})_{6}$ was reacted with relevant lithiated species of thiophene, 2,5dibromothiophene $\left(2,5-\mathrm{ThBr}_{2}\right)$ and 2,5-di(1'-bromoferrocenyl)thiophene (3) to form the respective metal acylates. After alkylation with methyl trifluoromethanesulfonate (MeOTf), neutral complexes were isolated as red/purple - dark brown solids. Complex 1 was previously synthesized and spectroscopically characterized, but single crystal x-ray diffraction data were not 
reported [6]. The ethoxy-analogue of compound $\mathbf{1}$ has also recently been electrochemically characterized [7].

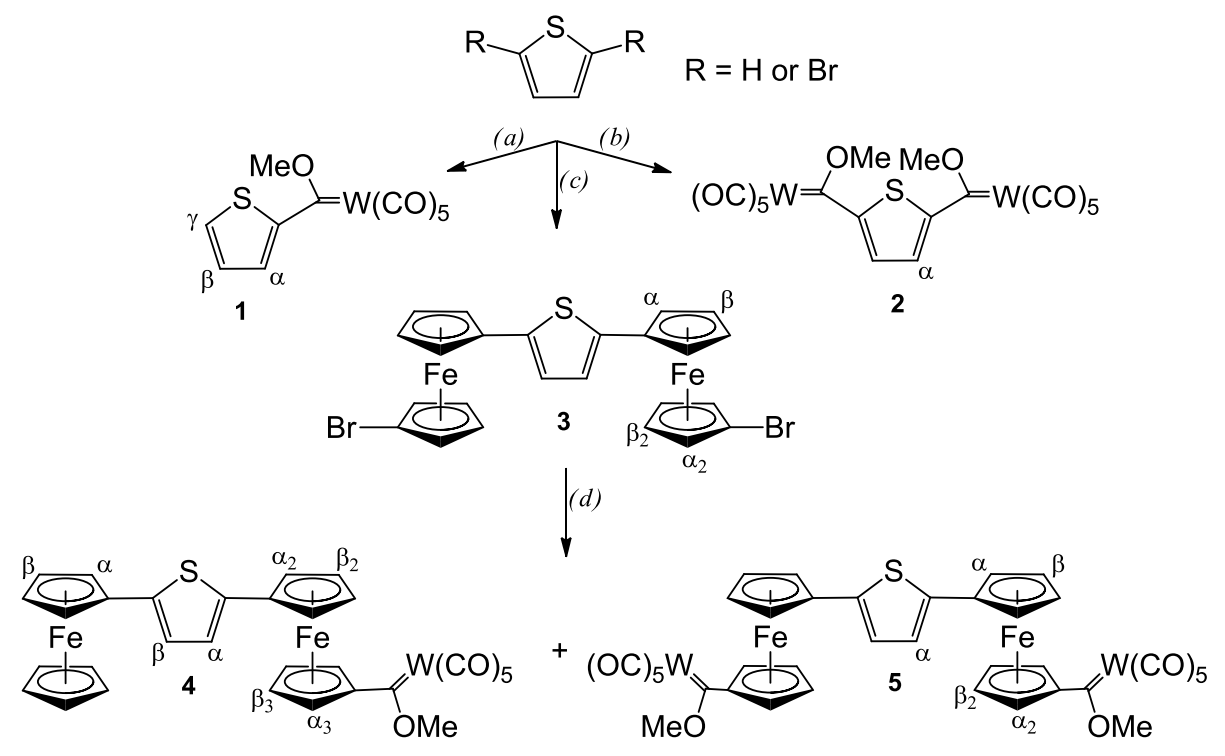

Scheme 1. Atom numbering scheme used for the series of complexes studied. Reaction conditions: (a) (i) $\mathrm{R}=\mathrm{H}$, thf, $-80{ }^{\circ} \mathrm{C},{ }^{n} \mathrm{BuLi}$; (ii) $\mathrm{W}(\mathrm{CO})_{6},-50{ }^{\circ} \mathrm{C}$; (iii) $\mathrm{CH}_{2} \mathrm{Cl}_{2},-50{ }^{\circ} \mathrm{C}$, MeOTf. (b) (i) $\mathrm{R}=\mathrm{Br}$, thf, $-40{ }^{\circ} \mathrm{C},{ }^{n} \mathrm{BuLi}$; (ii) $\mathrm{W}(\mathrm{CO})_{6},-40{ }^{\circ} \mathrm{C}$; (iii) $\mathrm{CH}_{2} \mathrm{Cl}_{2},-30{ }^{\circ} \mathrm{C}$, MeOTf. (c) (i) thf, $\mathrm{FcBr}_{2},-100{ }^{\circ} \mathrm{C},{ }^{n} \mathrm{BuLi}$; (ii) $\mathrm{ZnCl}_{2} \cdot 2 \mathrm{thf}, 0{ }^{\circ} \mathrm{C}$; (iii) $2,5-\mathrm{ThBr}_{2}$, [Pd], $55^{\circ} \mathrm{C}$. (d) (i) thf, $-40{ }^{\circ} \mathrm{C}$, ${ }^{n} \mathrm{BuLi}$; (ii) $\mathrm{W}(\mathrm{CO})_{6},-40{ }^{\circ} \mathrm{C}$; (iii) $\mathrm{CH}_{2} \mathrm{Cl}_{2},-30{ }^{\circ} \mathrm{C}$, MeOTf.

Lithiated thienyl/biferrocenylthiophenes were generated in situ from respective brominated precursors by lithiation or lithium-bromine exchange reactions according to literature procedures [8]. Purification of these complexes was done by column chromatography. Compounds $\mathbf{1}, \mathbf{2}, \mathbf{4}$ and $\mathbf{5}$ are stable toward moisture and air in the solid state and in solution. Compound $\mathbf{3}$ was synthesized by employing the palladium-promoted Negishi $C, C$ cross-coupling protocol [9] using 1,1'-dibromoferrocene and 2,5-dibromothiophene. The catalyst used was $\left[\mathrm{Pd}\left(\mathrm{CH}_{2} \mathrm{CMe}_{2} \mathrm{P}^{\mathrm{t}} \mathrm{Bu} 2\right)(\mu-\mathrm{Cl})\right][10]$. 
Table 1. Selected NMR data and the infrared $v(\mathrm{CO})$ stretching frequencies $\left(\mathrm{A}_{1} "\right)$ of Fischer carbenes 1, 2, 4 and 5 .

\begin{tabular}{cccc}
\hline Compd. & $\begin{array}{c}\mathrm{H}_{\alpha} \delta^{\mathrm{a}} \\
{ }^{1} \mathrm{H}[\mathrm{ppm}]\end{array}$ & $\begin{array}{c}\mathrm{C}_{\text {carbene }} \delta^{a} \\
{ }^{13} \mathrm{C}\left\{{ }^{1} \mathrm{H}\right\}[\mathrm{ppm}]\end{array}$ & $\begin{array}{c}\mathrm{A}_{1}{ }{ }^{v} \mathrm{v}(\mathrm{CO})^{b} \\
{\left[\mathrm{~cm}^{-1}\right]}\end{array}$ \\
\hline $\mathbf{1}$ & 8.17 & 293.39 & 2069 \\
$\mathbf{2}$ & 7.95 & 296.50 & 2062 \\
$\mathbf{4}$ & 4.93 & 307.75 & 2062 \\
$\mathbf{5}$ & 4.93 & 308.47 & 2060 \\
${ }^{a} \mathrm{CDCl}_{3} \cdot{ }^{b} \mathrm{CH}_{2} \mathrm{Cl}_{2}$. & &
\end{tabular}

The electronic effects of the carbene substituents in the named compounds can be followed in solution by both NMR and IR spectroscopy. The proton $\alpha$ to the carbene substituent in thienyl and ferrocenethiophenes experiences the greatest deshielding (Table 1) and corresponds well to the substituent effect of, for example, an ester functionality instead of a metal carbonyl fragment [11]. Stabilization of the electrophilic carbene carbon also occurs in a similar way as with the ester analogues: via $\pi$-delocalisation of the heteroaryl ring. As expected, this effect is also seen in the $\mathrm{A}_{1}$ " $\mathrm{CO}$ stretching frequency which decreases as electron density donation from the heteroatom increases [12]. Due to the relative insensitivity of the carbonyl stretching frequencies toward the changes on the carbene substituents [13], little difference is observed in the measured IR frequencies for this series of complexes.

\subsection{Electrochemistry}

The electrochemical studies of complexes 1, 2, 4 and 5 were carried out under an argon atmosphere in dichloromethane solutions containing $\left[\mathrm{N}^{n} \mathrm{Bu}_{4}\right]\left[\mathrm{B}\left(\mathrm{C}_{6} \mathrm{~F}_{5}\right)_{4}\right](0.1 \mathrm{M})$ as supporting electrolyte. An OTTLE [14] (Optically Transparent Thin Layer Electrochemistry) cell was used during the spectroelectrochemical investigations (Experimental Section). 
During the electrochemical study of 1, two significant redox events could be detected. A reduction process at $E_{p c}=-1745 \mathrm{mV}$, which is associated with the reduction of the carbene center itself, and a tungsten carbonyl oxidation reaction at $E_{p a}=820 \mathrm{mV}$ (Table 2 and Fig. 1). Similar observations were made for other Fischer carbene complexes previously [5-7]. Furthermore, a second tungsten carbene moiety on the thiophene system (2) results in a more anodic, irreversible tungsten oxidation process starting from $E_{p a}=850 \mathrm{mV}$ (Table 2 and Fig. 1). In contrast, two reversible [15] one-electron reduction events could be detected for 2 at $E^{0^{\prime}}=-1320$ $\mathrm{mV}$ and $-1060 \mathrm{mV}$, wherein the generation of the monoanion takes place around $600 \mathrm{mV}$ more anodic as observed for $\mathbf{1}$ (Table 2, Fig. 1). The corresponding redox separation $\left(\Delta E^{0^{\prime}}=260 \mathrm{mV}\right)$ suggests an interaction of the Fischer carbene moieties in $\mathbf{2}^{-}$over the thiophene bridge (vide infra).

A combination of the 2,5-diferrocenyl thiophene [16] system with one carbene fragment (4) results also in a significant anodic shift for the first ferrocenyl redox process compared to the 2,5-diferrocenyl thiophene [16]. The second iron-based oxidation process for 4 could be observed at $420 \mathrm{mV}$, further increasing of the potential leads to the typical irreversible tungsten carbonyl oxidation process around $1100 \mathrm{mV}$ s $\mathrm{FcH} / \mathrm{FcH}^{+}$(Table 2, Fig. 1). 

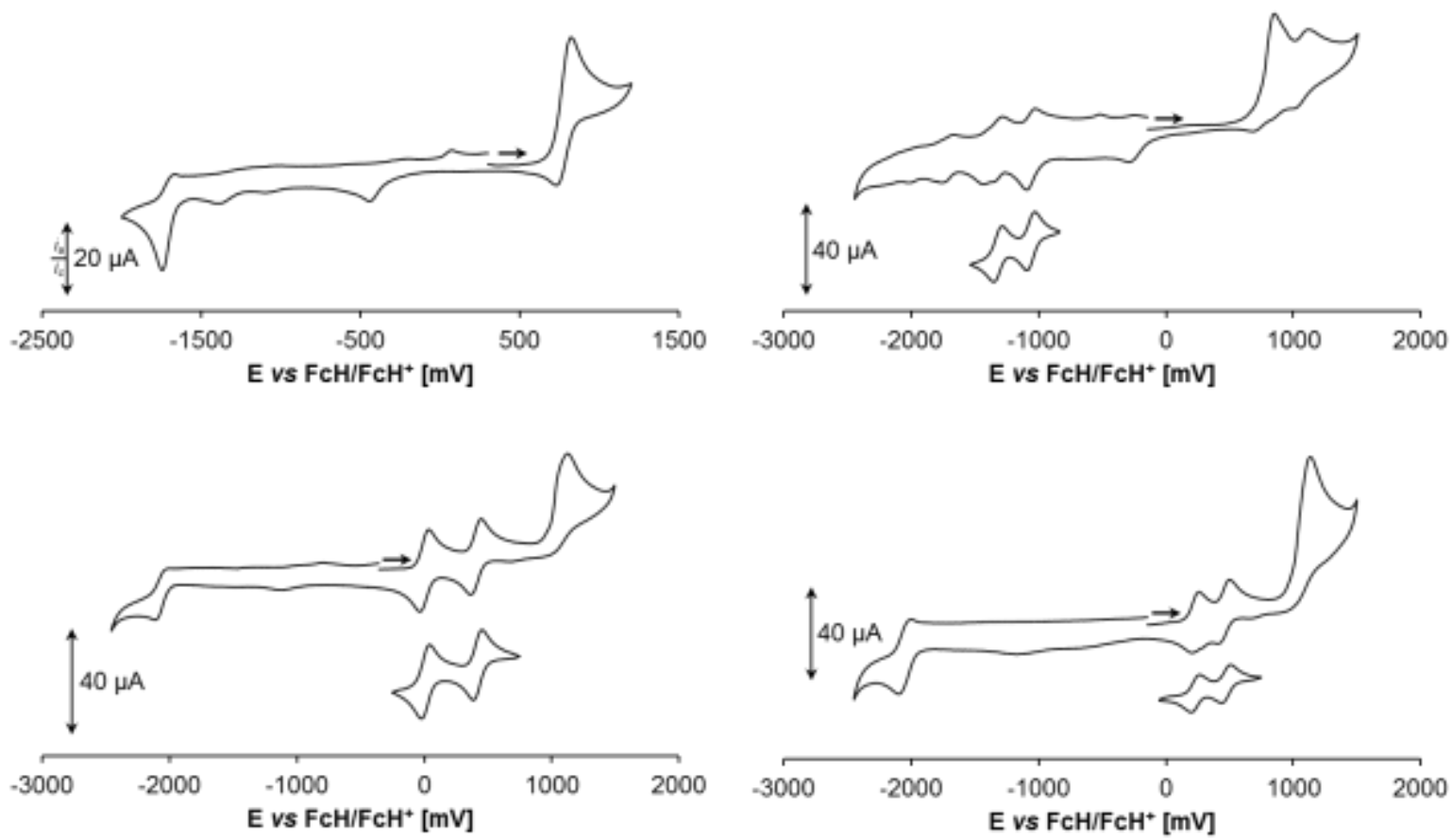

Fig. 1. Cyclic voltammograms of Fischer type carbenes 1 (left top), 2 (right top), 4 (left bottom) and $\mathbf{5}$ (right bottom). Scan rate: $100 \mathrm{mVs}^{-1}$ (full range cyclic voltammograms of $\mathbf{2}$ and $\mathbf{5}$ at 300 $\left.\mathrm{mVs}^{-1}\right)$ in dichloromethane solutions $\left(1.0 \mathrm{mmol}^{-1}\right)$ at $25{ }^{\circ} \mathrm{C}$, supporting electrolyte $\left[\mathrm{N}^{n} \mathrm{Bu}_{4}\right]\left[\mathrm{B}\left(\mathrm{C}_{6} \mathrm{~F}_{5}\right)_{4}\right]\left(0.1 \mathrm{~mol}^{-1} \mathrm{~L}^{-1}\right)$. In case of the full range cyclic voltammograms the initial cycle is shown, arrows indicate the potential direction. For cyclic voltammetry data see Table 2.

The generation of $4^{-}$could be detected at $E_{p c} \approx-210 \mathrm{mV}$. In case of the biscarbene 5, the first ferrocenyl based redox event was observed at $E^{0^{\prime}}=230 \mathrm{mV}$, approximately $220 \mathrm{mV}$ more anodic as detected for the corresponding $\mathbf{4} / \mathbf{4}^{+}$redox event, but even slightly more cathodic as for the previously described ferrocenyl tungsten Fischer carbene system [5]. The redox potential of the $\mathbf{5}^{+} / \mathbf{5}^{2+}$ process was determined to $E^{0^{\prime}}=475 \mathrm{mV} v s \mathrm{FcH} / \mathrm{FcH}^{+}$. Hence, the corresponding redox separation is very similar as observed for the 2,5-diferrocenyl thiophene system itself under comparable conditions (Table 2, Fig. 1) [16]. 
Table 2. Cyclic voltammetry data (potentials $v s \mathrm{FcH} / \mathrm{FcH}^{+}$) of $1.0 \mathrm{mmol} \mathrm{L}^{-1}$ solutions of 1, 2, 4 and 5 in dry dichloromethane containing $0.1 \mathrm{~mol}^{-1}$ of $\left[\mathrm{N}^{n} \mathrm{Bu}_{4}\right]\left[\mathrm{B}\left(\mathrm{C}_{6} \mathrm{~F}_{5}\right)_{4}\right]$ as supporting electrolyte at $25^{\circ} \mathrm{C}$.

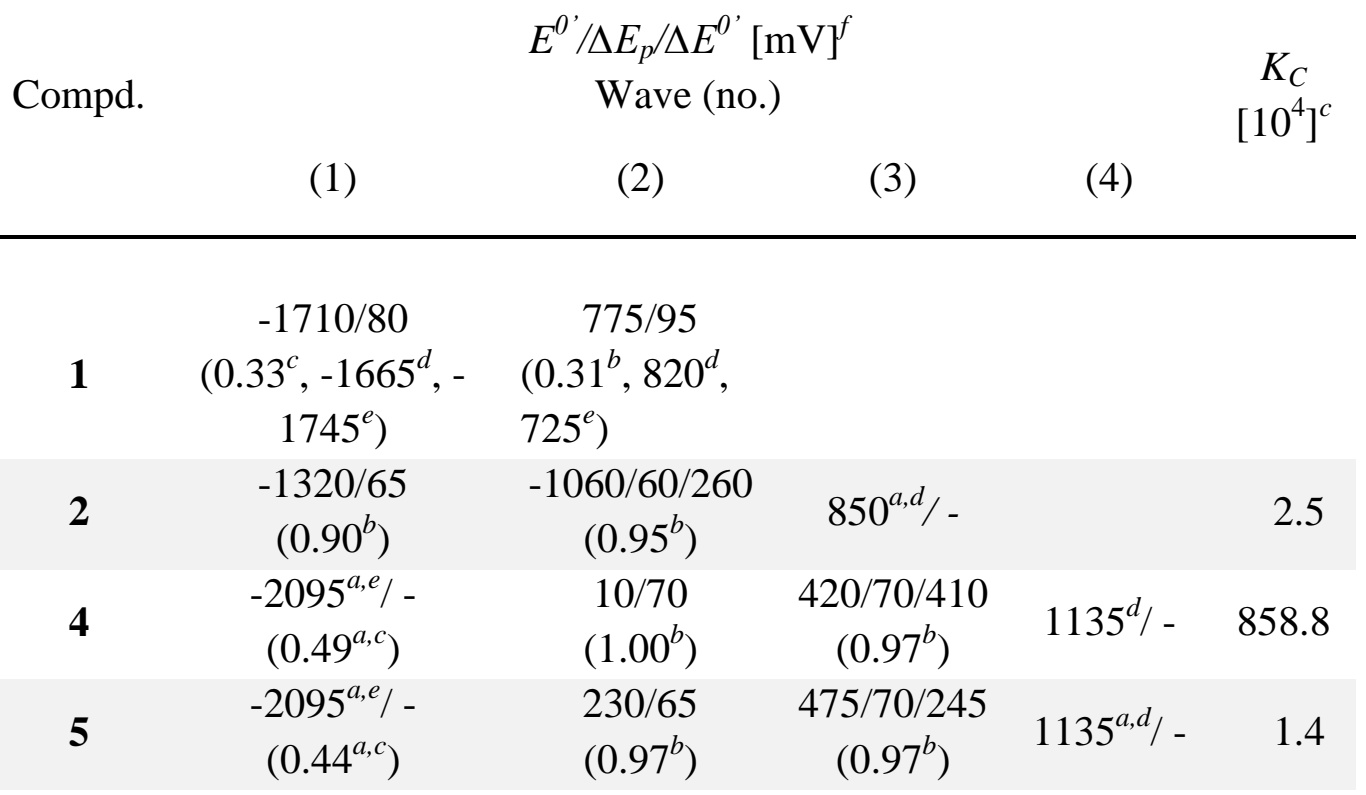

${ }^{a} 300 \mathrm{mVs} \cdot{ }^{-1} \cdot{ }^{b} i_{p d} / i_{p a} \cdot{ }^{c} i_{p a} / i_{p c} \cdot{ }^{d} E_{p a} \cdot{ }^{e} E_{p c} \cdot{ }^{f} E^{0^{\prime}}$ : Formal potential. $\Delta E_{p}$ : Difference between the oxidation $\left(E_{p a}\right)$ and reduction $\left(E_{p c}\right)$ peak potential $)[18] . \Delta E^{0^{\prime}}:$ Redox separation $\left(\Delta E^{0^{\prime}}=E^{0^{\prime}}(2)\right.$ $\left.E^{0^{\prime}}(1)\right) .{ }^{c} K_{C}$ : Comproportionation constant $\left(K_{C}=\left(e^{\frac{\Delta E^{0 \prime} F}{R T}}\right)\right)$.

A partial reversible reduction event could be detected in the cathodic end of the electrochemical window with an $i_{p c}$ value nearly twice as large as observed for the $\mathbf{5} / \mathbf{5}^{+}$process (Table 2, Fig.'s 1 and S-1) [17]. Thus, the reduction events of the Fischer carbene centers in 5 occur very close together. This fact suggests only a very weak interaction between the Fischer carbene increments. Similar findings were made for ferrocenediyl and biferrocenediyl biscarbene complexes recently [5]. The tungsten carbonyl oxidation electrode reactions of $\mathbf{5}$ were detected in the same potential range as observed for ferrocenyl thiophene 4 (Table 2, Fig. 1). 
In order to get a closer insight into the oxidation process of $\mathbf{2 , 4}$ and 5 spectroelectrochemical studies were carried out by a stepwise increase of the potential $v s \mathrm{Ag} / \mathrm{AgCl}$ in an OTTLE [14] cell using a $0.1 \mathrm{M}$ dichloromethane solution of $\left[\mathrm{N}^{n} \mathrm{Bu} 4\right]\left[\mathrm{B}\left(\mathrm{C}_{6} \mathrm{~F}_{5}\right)_{4}\right]$ as supporting electrolyte. This procedure allows for the in situ generation of intervalent species such as $\mathbf{2}^{\mathbf{n}-}, \mathbf{4}^{\mathbf{n +}}$ and $\mathbf{5}^{\mathbf{n +}}(\mathrm{n}=1$, 2). Within the deconvolution procedure of NIR absorptions, transitions with Gaussian shapes were taken to get fits good enough to allow an almost exact overlay of the sum of the spectral components with the experimental spectra.

All neutral Fischer carbene complexes do not display, as expected, any absorptions in the NIR range (Fig.'s 3, 4 and S-2). For calculation of the theoretical bandwidth at half height $\left(\Delta v_{1 / 2(\text { theo })}\right)$ in asymmetric systems, the energy gap between the diabatic states $\left(\Delta G^{0}\right)$ could be estimated, using the difference in oxidation potentials of the two redox sites [19]. Regarding this, the oxidation potential of $(\mathrm{CO})_{5} \mathrm{~W}=\mathrm{C}(\mathrm{OMe}) \mathrm{Me}[20]$ as well as the formal potential of the $\mathrm{Fc} / \mathrm{Fc}^{+}$ redox process of $(\mathrm{CO})_{5} \mathrm{~W}=\mathrm{C}(\mathrm{OMe}) \mathrm{Fc}[5]^{\text {Error! Bookmark not defined. }}$ were used (Table 3). Within the UV-Vis-NIR spectroelectrochemical investigations of 2 no noteworthy absorptions could be recorded in the NIR range (Fig. S-2). However, the strong UV-Vis absorptions of $\mathbf{2}$ around 340 $\mathrm{nm}$ and $550 \mathrm{~nm}$ decreases if reduction takes place and new absorption bands especially between $580 \mathrm{~nm}$ and $800 \mathrm{~nm}$ could be observed. Further reduction leads to a vanishing of the latter absorptions (Fig. S-2). 

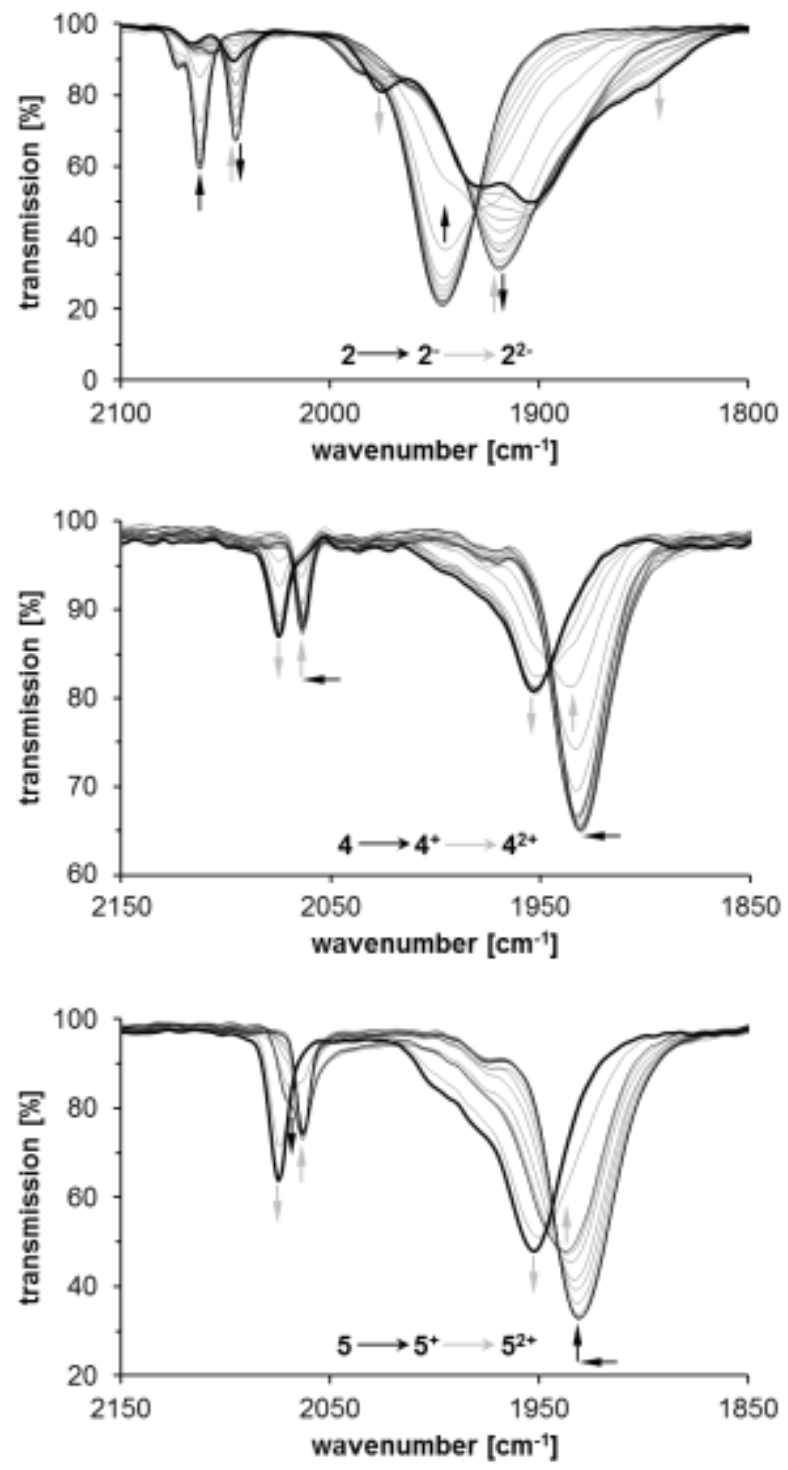

Fig. 2. Infrared spectra of $\mathbf{2 , 4}$ and $\mathbf{5}$ at rising potentials (top: -200 to $-750 \mathrm{mV}$; middle: -100 to $650 \mathrm{mV}$; bottom: -100 to $710 \mathrm{mV}$ ). All potentials $v s \mathrm{Ag} / \mathrm{AgCl}$ at $25{ }^{\circ} \mathrm{C}$ in dichloromethane on 5 $\mathrm{mM}$ analyte solutions, supporting electrolyte $\left[\mathrm{N}^{n} \mathrm{Bu}_{4}\right]\left[\mathrm{B}\left(\mathrm{C}_{6} \mathrm{~F}_{5}\right)_{4}\right](0.1 \mathrm{M})$. Arrows indicate increasing or decreasing as well as shifting absorptions.

During the infrared spectroelectrochemistry of 2, significant changes in $v(\mathrm{CO})$ stretching frequecies could be detected during the successive in situ generation of $\mathbf{2}^{-}$(Fig. 2). Thus, the absorption of the original $\mathrm{A}_{1}$ " mode, at $2062 \mathrm{~cm}^{-1}$ decreases together with an rising absorption band at $2045 \mathrm{~cm}^{-1}$ (Fig. 2). This suggests a significant interaction between the two Fischer 
carbene increments over the thiophene connectivity within the infrared timescale. Furthermore, the $v(\mathrm{CO})$ stretching frequencies of 2 at $1947 \mathrm{~cm}^{-1}$ shift formal to $1920 \mathrm{~cm}^{-1}$ upon generation of the monoanion (Fig. 2).

Further reduction to $2^{2-}$ leads to a decrease of the $A_{1} " v(C O)$ stretching frequencies in combination with a formal splitting of the band at $1920 \mathrm{~cm}^{-1}$ to $1928 \mathrm{~cm}^{-1}$ and $1905 \mathrm{~cm}^{-1}$ (Fig. 2). However, under our conditions a slow decomposition process could be observed during the generation of $\mathbf{2}^{2-}$ (see also Fig. S-2) and hence the corresponding absorption behavior should be handled with caution. During the infrared spectroelectrochemical study of ferrocenyl thiophene 4, v(CO) stretching frequencies were observed at $2063 \mathrm{~cm}^{-1}$ and $1930 \mathrm{~cm}^{-1}$ (Fig. 2).

Upon increasing the potential, the original absorptions shift only slightly to higher wavenumbers during the generation of $\mathbf{4}^{+}\left(2064 \mathrm{~cm}^{-1}\right.$ and $1932 \mathrm{~cm}^{-1}$, Fig. 2). This observation reveals that the first oxidation is mostly based on the non-substituted ferrocenyl unit and the interaction with the Fischer carbene moiety is nearly negligible. Further increasing the potential leads to a decrease of the latter bands and $v(\mathrm{CO})$ stretching frequencies at $2075 \mathrm{~cm}^{-1}$ and 1953 $\mathrm{cm}^{-1}$ were for $4^{2+}$. Within this regard, the shift in $v(\mathrm{CO})$ stretching frequencies upon generation of $4^{2+}$ is comparable with the corresponding behavior of the ferrocenyl tungsten Fischer carbene complex, $(\mathrm{CO})_{5} \mathrm{~W}=\mathrm{C}(\mathrm{OMe}) \mathrm{Fc}$, itself during the $\mathrm{Fc} / \mathrm{Fc}^{+}$redox process [5]. Thus, the interaction between the ferrocenyl unit and the Fischer carbene moiety should be very similar in both cases. Regarding this, UV-Vis-NIR spectroelectrochemical studies of 4 were carried out. Thus, during the oxidation process of 4 typical absorptions in the UV-Vis region of inner ferrocenyl transitions $\left(\pi-\pi^{*}\right.$ and MLCT/d-d) were observed (Fig. 3) [21]. Upon generation of $\mathbf{4}^{+}$three main absorptions could be detected in the NIR range. A high energy near infrared absorption was observed around $10500 \mathrm{~cm}^{-1}$ which is assigned to a ligand to metal charge transfer (LMCT) 
transition, similar as observed for the monocationic intermediate of 2,5-diferrocenyl thiophene as well as for other ferrocenyl-substituted heterocycles $[16,22,23]$. An observation of an absorption, caused by an ferrocenyl-tungsten interaction (MMCT), is not expected and can be excluded for $4^{+}$, due to the very small shift in $v(\mathrm{CO})$ stretching frequencies (vide supra). Furthermore, the relative strong absorption at $6600 \mathrm{~cm}^{-1}$ is assigned to an intervalence charge transfer (IVCT) between the iron centers in $\mathbf{4}^{+}$(Table 3).

Table 3. NIR data of 4 and $5(2 \mathrm{mM})$ in dry dichloromethane containing $\left[\mathrm{N}^{n} \mathrm{Bu}_{4}\right]\left[\mathrm{B}\left(\mathrm{C}_{6} \mathrm{~F}_{5}\right)_{4}\right]$ $(0.1 \mathrm{M})$ as supporting electrolyte at $25^{\circ} \mathrm{C}$.

\begin{tabular}{|c|c|c|c|c|}
\hline Compd. & Transition & $v_{\max }\left[\mathrm{cm}^{-1}\right]$ & $\Delta v_{1 / 2}\left[\mathrm{~cm}^{-1}\right]$ & $\Delta v_{1 / 2 \text { (theo) }}\left[\mathrm{cm}^{-1}\right]^{a}$ \\
\hline \multirow{4}{*}{$4^{+}$} & LMCT & 10460 & 3280 & \multirow{4}{*}{$3100^{b, e}$} \\
\hline & IVCT & 6600 & 3220 & \\
\hline & LF & 5140 & 720 & \\
\hline & & 4080 & 730 & \\
\hline \multirow{3}{*}{$4^{2+}$} & LMCT & 10800 & n. a. & \multirow{3}{*}{$1750^{b, d}$} \\
\hline & MMCT & 7220 & 3130 & \\
\hline & LF & 3950 & 1240 & \\
\hline \multirow{3}{*}{$5^{+}$} & LMCT/MMCT & 9170 & 2920 & $2750^{b, d}$ \\
\hline & IVCT & 4660 & 4200 & \multirow[t]{2}{*}{$3280^{c}$} \\
\hline & & 3610 & 900 & \\
\hline \multirow{3}{*}{$5^{2+}$} & LMCT & 10200 & n. a. & \multirow{3}{*}{$1572^{b, d}$} \\
\hline & MMCT & 6970 & 3800 & \\
\hline & LF & 4000 & 1000 & \\
\hline
\end{tabular}

The significant blue shift of the latter transition together with the significant smaller bandwidth at half height, as we would observe for a symmetrical system in the same energy range, 
compared with the corresponding absorption of the monocationic 2,5-diferrocenyl thiophene [16] is caused by the asymmetry in $\mathbf{4}\left(\mathbf{4}^{+}\right.$, Table 3$)$. Due to the fact that delocalization is not favored in asymmetrical systems and together with the estimation of the corresponding theoretical bandwidth at half height for such species, the metal-metal interaction in $4^{+}$can be assigned to a class II system according to Robin and Day [24].
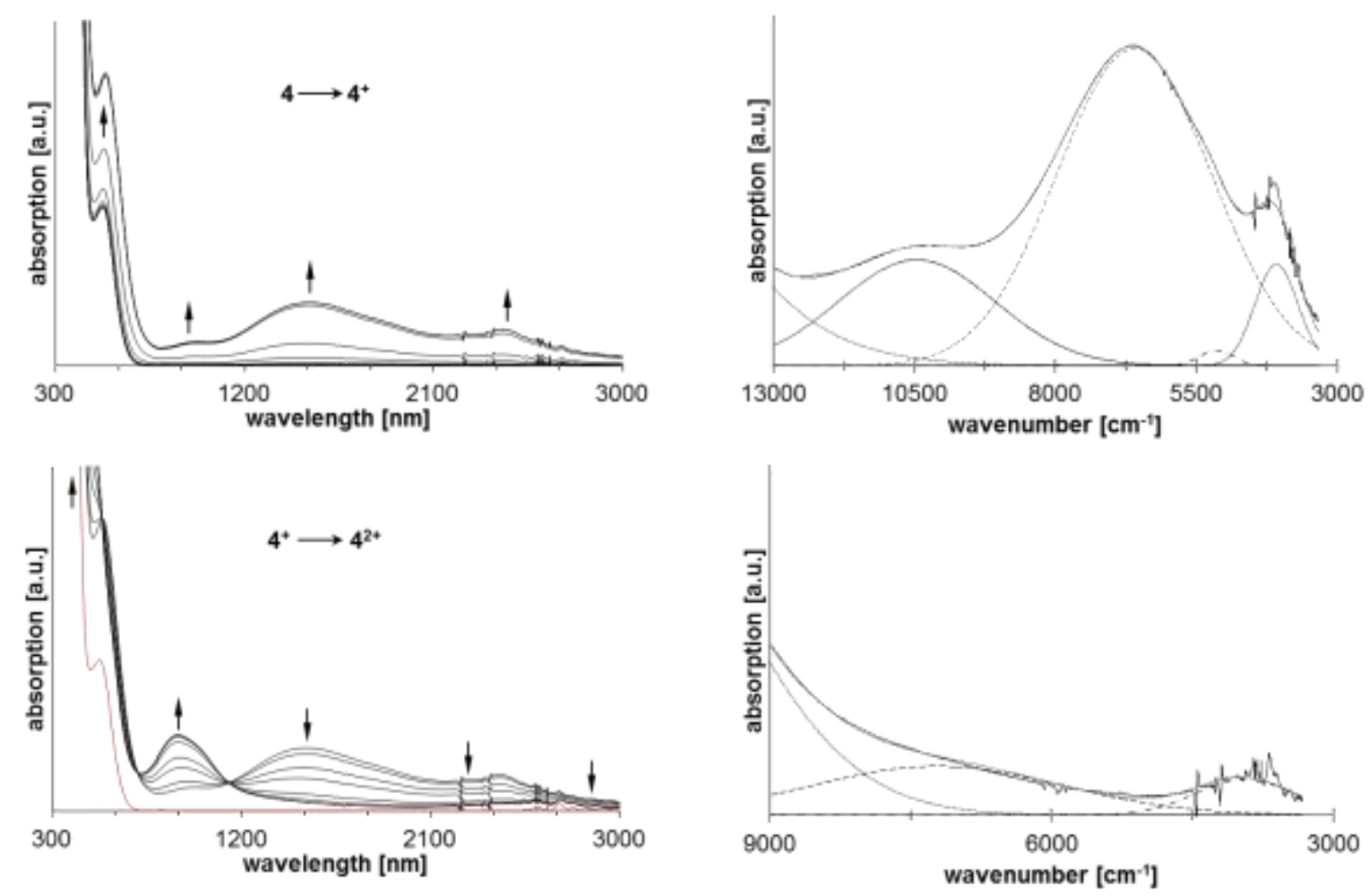

Fig. 3. UV-Vis/NIR spectra of $4(2 \mathrm{mM})$ at rising potentials. Left top: -100 to $390 \mathrm{mV}$. Left bottom: 390 to $525 \mathrm{mV}$ (red line represents rereduction to the neutral species). Right top: deconvolution of NIR absorptions at $390 \mathrm{mV}$, using five distinct overlapping transitions with Gaussian shapes (dashed line indicates IVCT absorptions, dotted line corresponds to absorptions caused by interactions between ligand and metal, dotted dashed line represents ligand field transitions).Right bottom: deconvolution of NIR absorptions at $525 \mathrm{mV}$, using three distinct overlapping transitions with Gaussian shapes (dashed line indicates MMCT absorptions, dotted line corresponds to absorptions caused by interactions between ligand and metal, dotted dashed line represents ligand field transitions). All potentials $v s \mathrm{Ag} / \mathrm{AgCl}$ at $25^{\circ} \mathrm{C}$ in dichloromethane, supporting electrolyte $\left[\mathrm{N}^{n} \mathrm{Bu}_{4}\right]\left[\mathrm{B}\left(\mathrm{C}_{6} \mathrm{~F}_{5}\right)_{4}\right](0.1 \mathrm{M})$. Arrows indicate increasing or decreasing as well as shifting absorptions. 
The low energy absorption at $4080 \mathrm{~cm}^{-1}$, which is too intense for an ligand field transition, is often ascribed to a further LMCT/IC [25] absorption, since the experimental determined bandwidth at half height would be too small as expected from the hush theory, however Tuczek et al. have proposed an IVCT character for such absorptions in intervalent non-bridged biferrocene species, similar as common accepted for bifulvalene diiron systems (Table 3, Fig. 3) $[26,27]$.

Further increasing of the potential leads to a decrease of the low energy absorptions upon generation of $4^{2+}$ together with an in-creasing LMCT absorption band around $11000 \mathrm{~cm}^{-1}$. An absorption band at $7220 \mathrm{~cm}^{-1}$ could be assigned to a MMCT between ferrocenyl unit and its tungsten Fischer carbene substituent, similar as observed for the corresponding ferrocenyl and biferrocenyl systems previously [5]. The weak absorption at ca. $4000 \mathrm{~cm}^{-1}$ is ascribed to a formal forbidden ligand field transitions $[16,23,28]$. A second tungsten Fischer complex fragment on the $\alpha, \alpha^{\prime}$-diferrocenyl thiophene building block (5) leads to three NIR absorptions for $\mathbf{5}^{+}$at 9170 $\mathrm{cm}^{-1}$, around $4700 \mathrm{~cm}^{-1}$ and at $3610 \mathrm{~cm}^{-1}$ (Table 3, Fig. 4). The latter transition can again be assigned to a low energy LMCT/IC (vide supra). The more intense absorption at $4660 \mathrm{~cm}^{-1}$ is described with the well-known formal iron-iron inter valence charge transfer, similar as observed previously [16,23]. A comparison of the corresponding bandwidth at half height with the theoretical value reveals also a class II assignment, according to Robin and Day (Table 3, Fig. 4) [24]. The third near infrared transition around $9200 \mathrm{~cm}^{-1}$ for $5^{+}$could be ascribed with an LMCT transition (vide supra) between the thiophene core and the ferrocenyls, however it can also be an combination together with a ferrocenyl-tungsten MMCT transition (Table 3 and Fig. 4). 

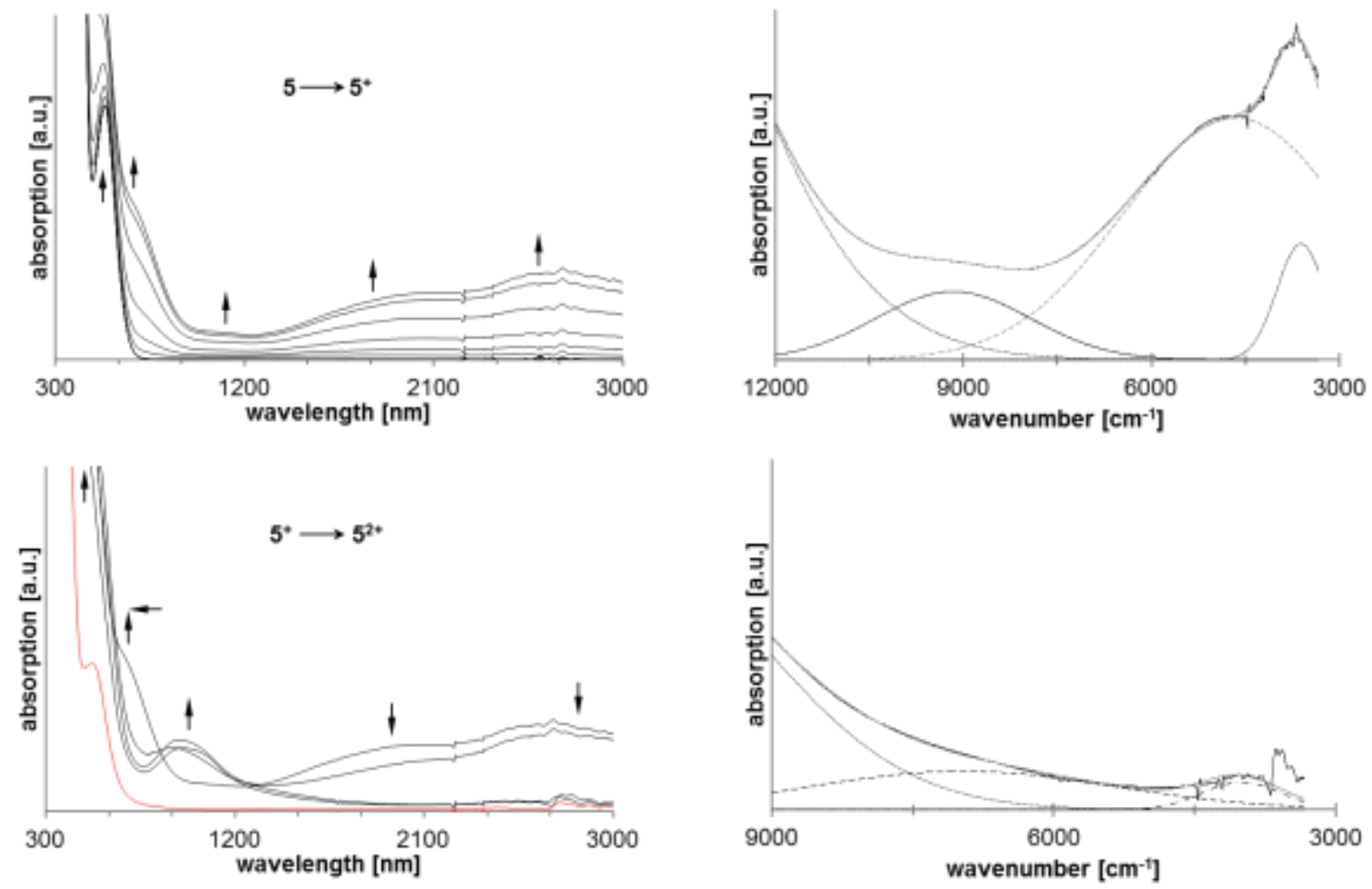

Fig. 4. UV-Vis/NIR spectra of $5(2 \mathrm{mM})$ at rising potentials. Left top: -100 to $670 \mathrm{mV}$. Left bottom: 670 to $710 \mathrm{mV}$ (red line represents rereduction to the neutral species). Right top: deconvolution of NIR absorptions at $670 \mathrm{mV}$, using four distinct overlapping transitions with Gaussian shapes (dashed line indicates IVCT absorptions, dotted line corresponds to absorptions caused by interactions between ligand and metal).Right bottom: deconvolution of NIR absorptions at $710 \mathrm{mV}$, using three distinct overlapping transitions with Gaussian shapes (dashed line indicates MMCT absorptions, dotted line corresponds to absorptions caused by interactions between ligand and metal, dotted dashed line represents ligand field transitions). All potentials $v s$ $\mathrm{Ag} / \mathrm{AgCl}$ at $25{ }^{\circ} \mathrm{C}$ in dichloromethane, supporting electrolyte $\left[\mathrm{N}^{n} \mathrm{Bu}_{4}\right]\left[\mathrm{B}\left(\mathrm{C}_{6} \mathrm{~F}_{5}\right)_{4}\right](0.1 \mathrm{M})$. Arrows indicate increasing or decreasing as well as shifting absorptions.

During the successive generation of monocationic $\mathbf{5}$ the $v(\mathrm{CO})$ stretching frequencies at 1931 $\mathrm{cm}^{-1}$ shifts formally to higher energy at $1937 \mathrm{~cm}^{-1}$ together with an occurrence of a double band for the $A_{1}{ }^{\prime \prime} v(C O)$ stretching frequencies $\left(2070 \mathrm{~cm}^{-1}\right.$ and $\left.2063 \mathrm{~cm}^{-1}\right)$, verifying the valence trapped situation in $\mathbf{5}^{+}$(Fig. 2). Upon oxidation of $\mathbf{5}^{+}$, the low NIR absorptions decreases and the high energy absorption bands around $1000 \mathrm{~nm}$ become more intense (Table 3, Fig. 3). 
Furthermore, absorption bands at $6970 \mathrm{~cm}^{-1}$ (MMCT) and around $4000 \mathrm{~cm}^{-1}$ (LF) could be detected (Table 3 and Fig. 4). However, a slow decomposition of $\mathbf{5}^{\mathbf{2}}$ could be observed during the spectroelectrochemical measurements, thus the corresponding absorption behavior should be handled with care.

In the infrared range, the $v(\mathrm{CO})$ stretching frequencies at $2070 \mathrm{~cm}^{-1}, 2063 \mathrm{~cm}^{-1}$ and $1937 \mathrm{~cm}^{-1}$ decrease upon generation of $\mathbf{5}^{\mathbf{2 +}}$ together with increasing absorptions at $2075 \mathrm{~cm}^{-1}$ and $1953 \mathrm{~cm}^{-1}$, very similar as observed during the generation of the cation of $(\mathrm{CO})_{5} \mathrm{~W}=\mathrm{C}(\mathrm{OMe}) \mathrm{Fc}^{\text {Error! Bookmark }}$ not defined. Hence, a class II assignment according to Robin and Day should be valid [24].

\subsection{Crystallography}

The molecular structures of $\mathbf{1}, \mathbf{4}$ and $\mathbf{5}$ in the solid state have been determined by single-crystal X-ray diffraction analysis. Suitable single crystals of 1, 4 and 5 were obtained by slow evaporation of a saturated dichloromethane solution of the respective complex layered with $n$ hexane at $-5{ }^{\circ} \mathrm{C}$. The ORTEP diagrams with selected bond lengths $(\AA)$, bond angles $\left({ }^{\circ}\right)$, and torsion angles $\left({ }^{\circ}\right)$ are shown in Fig.'s $5-7$. Compounds 1, 4 and 5 crystallize in the triclinic space group $P-1(5)$ or in the monoclinic space group $P 2_{1} / n(4,1)$ with one $(4,1)$ or a half molecule (5) in the asymmetric unit. The thiophene heterocycle in $\mathbf{5}$ is refined disordered on two positions with an occupation of $50 \%$ for each orientation and is omitted for clarity in Fig. 5.

The ferrocenyl containing derivatives $\mathbf{4}$ and $\mathbf{5}$ show an almost planar conformation between the thiophene and the cyclopentadienyl cycles $\left(5\right.$ : $\mathrm{C} 14-\mathrm{C} 13-\mathrm{C} 18-\mathrm{C} 19-16(3){ }^{\circ}, 4: \mathrm{C} 14-\mathrm{C} 13-\mathrm{C} 18-$ $\mathrm{C} 19176.6(5)^{\circ}$ and $\left.\mathrm{C} 20-\mathrm{C} 21-\mathrm{C} 22-\mathrm{C} 261.1(8)^{\circ}\right)$ and also to the planar carbene substituent (5: O6-C6-C8-C9 1.3(9) ${ }^{\circ}, 4$ : O6-C6-C8-C9-0.2(6) $\left.{ }^{\circ}\right)$. A directly bonded heterocycle (1) also 
obtains a planar conformation between the carbene and the thiophene $\pi$-system (O6-C6-C8-C9 $\left.-170.9(4)^{\circ}\right)$.

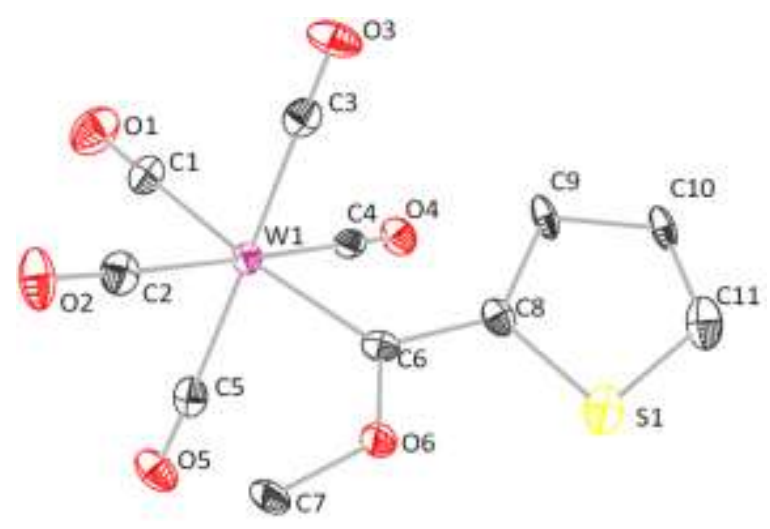

Fig. 5. ORTEP diagram (50\% probability level) of the molecular structure of $\mathbf{1}$ with the atomnumbering scheme. All hydrogen atoms have been omitted for clarity. Selected bond distances $(\AA)$, angles $\left({ }^{\circ}\right)$, and torsion angles $\left({ }^{\circ}\right)$ : C1-O1 1.140(6), C1-W1 2.030(5), C6-O6 1.330(5), C6C8 1.461(6), C6-W1 2.180(5), O6-C7 1.449(5), C8-C9 1.476(6), C9-C10 1.436(6), C10-C11 1.354(5), C11-S1 1.678(5), C8-S1 1.725(5), O1-C1-W1 177.8(4), O6-C6-C8 105.1(4), O6C6-W1 130.1(3), C8-C6-W1 124.8(3), C11-S1-C8 92.1(2), O6-C6-C8-C9 -170.9(4), W1C6-C8-C9 11.6(6), C8-C6-O6-C7 179.3(3), O6-C6-W1-C5-49.7(4)

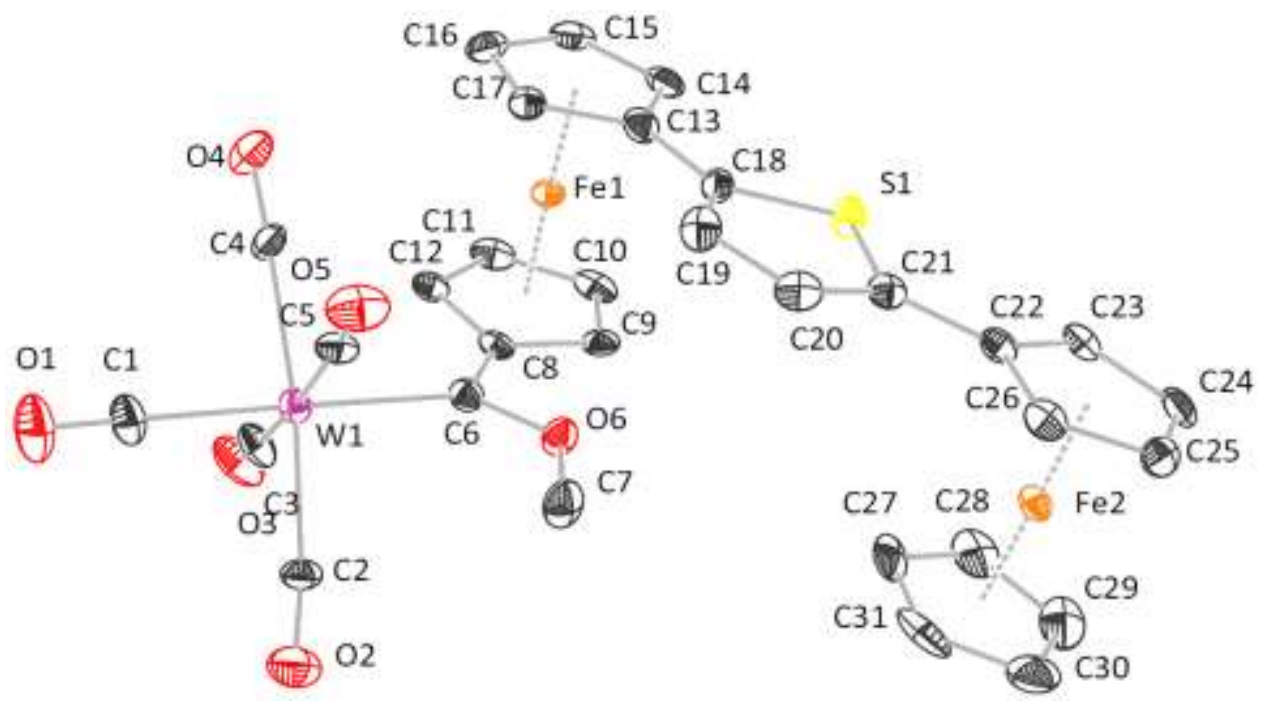

Fig. 6. ORTEP diagram (50\% probability level) of the molecular structure of 4 with the atomnumbering scheme. All hydrogen atoms have been omitted for clarity. Selected bond distances $(\AA)$, angles $\left({ }^{\circ}\right)$, and torsion angles $\left(^{\circ}\right)$ : C1-O1 1.129(6), C1-W1 2.046(5), C6-W1 2.202(4), C6- 
O6 1.334(5), O6-C7 1.436(6), C6-C8 1.453(6), C13-C18 1.458(7), C18-C19 1.361(7), C19C20 1.417(7), C20-C21 1.357(7), C18-S1 1.725(5), C21-S1 1.741(4), C21-C22 1.446(6), D1Fe1 1.6467(7), D2-Fe1 1.6558(7), D3-Fe2 1.6328(7), D4-Fe2 1.6425(7), O1-C1-W1 176.6(4), O6-C6-C8 105.6(4), O6-C6-W1 128.9(3), C8-C6-W1 125.4(3), C18-S1-C21 92.4(2), D1Fe1-D2 177.17(5), D3-Fe2-D4 179.00(5), O6-C6-C8-C9 -0.2(6), W1-C6-O6-C7 1.0(6), C14-C13-C18-C19 176.6(5), C20-C21-C22-C26 1.1(8), O6-C6-W1-C2 -41.3(4), C8-D1D2-C17 -16.8(3), C8-D1-D2-C13 55.2(3), C22-D3-D4-C27 3.8(4), Fe-Fe 7.4837(10) (D denote the centroids of: D1: C8-C12, D2 C13-C17, D3 C22-C26, D4 C27-C31).

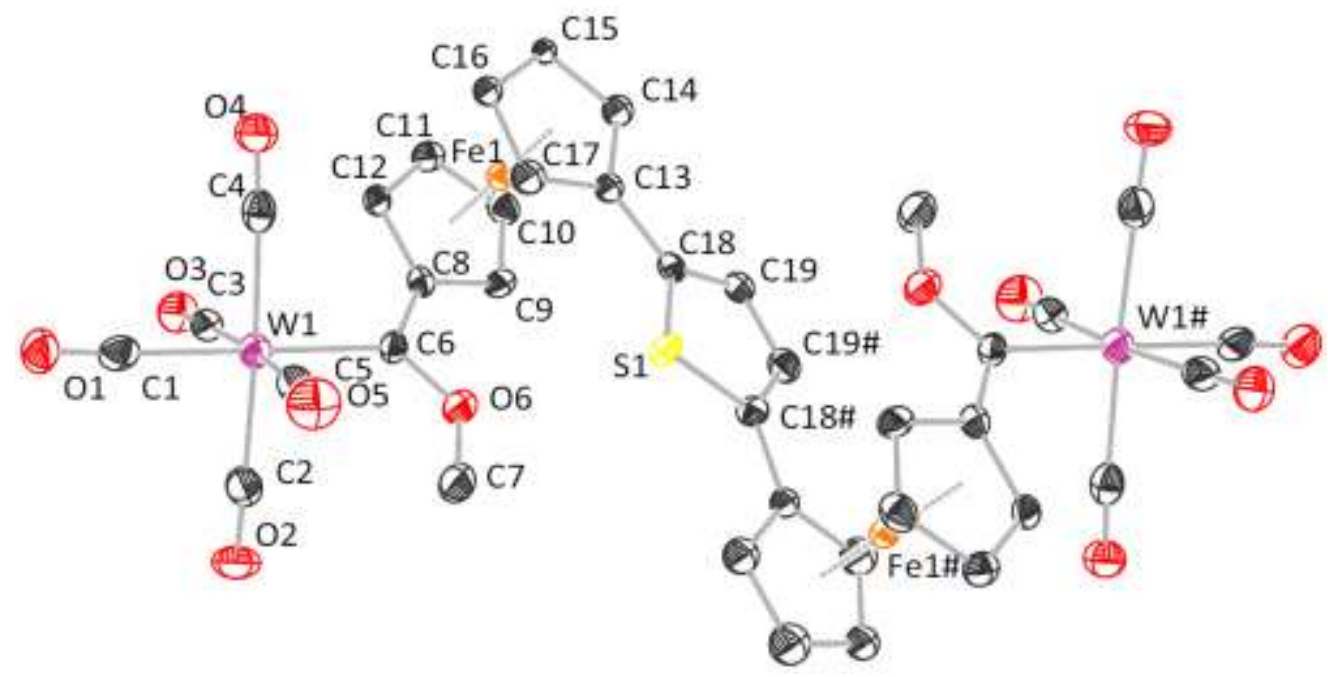

Fig. 7. ORTEP diagram (50\% probability level) of the molecular structure of 5 with the atomnumbering scheme. All hydrogen atoms have been omitted for clarity. Selected bond distances $(\AA)$, angles $\left(^{\circ}\right)$, and torsion angles $\left(^{\circ}\right)$ : C1-O1 1.139(9), C1-W1 2.030(8), C6-W1 2.222(7), C6O6 1.328(8), C6-C8 1.461(9), O6-C7 1.425(8), C13-C18 1.45(2), C18-C19 1.406(19), C18-S1 1.707(13), C19-C19\# 1.367(19), D1-Fe1 1.6552(9), D2-Fe1 1.6990(9), O1-C1-W1 177.0(6), C18-S1-C18\# 93.3(7), C8-C6-W1 124.9(5), O6-C6-W1 128.5(5), O6-C6-C8 106.3(6), D1Fe1-D2 178.76(7), C8-D1-D2-C17-4(1), C8-D1-D2-C13 67.2(8), C8-C6-O6-C7 178.2(6), O6-C6-W1-C2 -41.5(6), O6-C6-C8-C9 1.3(9), C14-C13-C18-C19-16(3), Fe1-Fe1\# $8.4367(2)$ (D1 denotes the centroid of C8-C12; D2 denotes the centroid of C13-C17). Symmetry operation for the generation of equivalent atoms: $-\mathrm{x}-1,-\mathrm{y},-\mathrm{z}$ 
The ferrocenyls themselves are almost eclipsed (5: C8-D1-D2-C17 -4(1) ${ }^{\circ}, 4$ : C22-D3-D4$\left.\mathrm{C} 273.8(4)^{\circ}\right)$ or between eclipsed and staggered (4: C8-D1-D2-C17-16.8(3) ${ }^{\circ}$ ) with a synclinal conformation for 1,1'-substituted ferrocenyl fragments. Nevertheless, the substituents at the carbene carbon C6 influence the W1-C6 distance. Electron rich metallocenyl moieties lead to an extension of the formal double bond to a maximum of 2.222(7) $\AA$ (5), whereas the thiophene derivative 1 significantly shortens the bond to 2.180(5) $\AA$. In 4 the distances are averaged to 2.202(4) $\AA$. A further influence to the W1-C1 distance is not detectable. Regarding the bond lengths in the thiophene core for unsymmetrical $\mathbf{1}$, the carbene carbon influences the $\mathrm{C}-\mathrm{S}$ bonds. The bond length from $\mathrm{S} 1$ to $\mathrm{C} 8$ is $1.725(5) \AA$, whereas to the non-substituted bond to $\mathrm{C} 11$ is shortened to 1.678(5) $\AA$. The free electron pairs of O6 are oriented away from the carbonyls for all three compounds to avoid an electronic interaction. The steric interaction of the methyl group at $\mathrm{C} 7$ to the $\mathrm{W}(\mathrm{CO})_{5}$ fragment is prevented by a staggered conformation between two carbonyls (5: O6-C6-W1-C2 -41.5(6) ${ }^{\circ}, 4$ : O6-C6-W1-C2 -41.3(4) ${ }^{\circ}, 1$ : O6-C6-W1-C5 -49.7(4) ${ }^{\circ}$ ). Nevertheless, the $\mathrm{W}(\mathrm{CO})_{5}$ fragment decreases the O6-C6-C8 angle from ideal $120^{\circ}$ to $106.3(6)$ (5), 105.6(4) (4) and 105.1(4) (1).

\section{Conclusions}

Within this study, a series of thiophene tungsten Fischer carbene complexes of type $\left[(\mathrm{CO})_{5} \mathrm{~W}=\mathrm{C}(\mathrm{OMe}) \mathrm{R}\right](\mathbf{1}, \mathrm{R}=2-\mathrm{Th} ; \mathbf{3}, \mathrm{R}=\mathrm{fcthFc})$ and $\left[(\mathrm{CO})_{5} \mathrm{~W}=\mathrm{C}(\mathrm{OMe})-\mathrm{R} '-(\mathrm{OMe}) \mathrm{C}=\mathrm{W}(\mathrm{CO})_{5}\right]$ $\left(\mathbf{2}, R^{\prime}=\right.$ th; $\mathbf{5}, R^{\prime}=$ fcthfc $)$ is reported with the aim of investigating low energy charge transfer transitions between the carbene substituents and the transition metal carbonyl fragment incorporating the thiophene system $(\mathrm{Th}=$ Thienyl; th $=2,5$-thiendiyl; $\mathrm{Fc}=$ ferrocenyl; $\mathrm{fc}=1,1$ 'ferrocenediyl). For this reason, tungsten Fischer carbene functionalized thiophene and $\alpha, \alpha^{\prime}-$ 
diferrocenyl thiophene complexes $\mathbf{1}, \mathbf{2}, \mathbf{4}$ and $\mathbf{5}$ were prepared and characterized spectroscopically in solution. The structural properties of $\mathbf{2}, \mathbf{4}$ and $\mathbf{5}$ in the solid state were investigated by single-crystal X-ray diffraction studies.

The electrochemical studies reveal reversible one electron redox events for the ferrocenyl moieties. Moreover, typical electrode reactions could be found for the carbene reductions itself and for the tungsten carbonyl oxidation processes. However, for the biscarbene $\mathbf{2}$ two wellseparated one-electron reduction events could be found. During the UV-Vis-NIR spectroelectrochemical investigations typical low energy absorptions for the mixed-valent $\alpha, \alpha^{\prime}-$ diferrocenyl thiophene increment were found, as well as high energy NIR absorptions which were attributed to metal-metal charge transfer transition between the tungsten carbonyl increment and the ferrocenyl units in the corresponding species. Further infrared spectroelectrochemical studies reveal that the electronic interactions in the corresponding cationic species can be described with weakly coupled class II systems according to Robin and Day.

\section{Experimental Section}

\subsection{General Procedures}

Inert Schlenk techniques were employed in all operations and syntheses were done under argon or nitrogen. Solvents were distilled over sodium/benzophenone ( $n$-hexane, tetrahydrofuran (thf)) or phosphorpentoxide (dichloromethane $(\mathrm{dcm})$ ) and collected under nitrogen or argon gas. Chemicals were used as purchased without any further purification unless stated otherwise. Purification with column chromatography was done using silica gel $60(0.0063-0.200 \mathrm{~mm})$ as 
stationary phase. A Bruker AVANCE 500 spectrometer was used for NMR recordings. ${ }^{1} \mathrm{H}$ NMR spectra were recorded at $500.139 \mathrm{MHz}$ and ${ }^{13} \mathrm{C}\left\{{ }^{1} \mathrm{H}\right\} \mathrm{NMR}$ spectra at $125.75 \mathrm{MHz}$. The signal of the solvent was used as reference: ${ }^{1} \mathrm{H} \mathrm{CDCl}_{3}$ at $7.26 \mathrm{ppm}$ and ${ }^{13} \mathrm{C}\left\{{ }^{1} \mathrm{H}\right\} \mathrm{CDCl}_{3}$ at $77.16 \mathrm{ppm}$. IR spectra were recorded on a Perkin-Elmer Spectrum RXI FT-IR spectrophotometer in solvent as specified. Only the vibration bands in the carbonyl-stretching region $\left(1600-2200 \mathrm{~cm}^{-1}\right)$ were recorded.

\subsection{Synthesis of complex [6]}

To a thf solution of thiophene $(3.0 \mathrm{mmol}, 0.24 \mathrm{~mL}),{ }^{n} \mathrm{BuLi}(3.3 \mathrm{mmol})$ was slowly added at -80 ${ }^{\circ} \mathrm{C}$. After $1 \mathrm{~h}$ the cold bath was removed and the reaction mixture allowed to reach room temperature. It was cooled to $-50{ }^{\circ} \mathrm{C}$ and $\mathrm{W}(\mathrm{CO})_{6}(3.0 \mathrm{mmol}, 1.06 \mathrm{~g})$ was added in a single portion. The colour of the solution turned red upon addition. The reation mixture was stirred isotherm for $30 \mathrm{~min}$ after which it was stirred for an additional hour at $\mathrm{rt}$. Volatiles were removed by reduced pressure and the residue redissolved in dcm. Afterwards, the reaction mixture was cooled to $-50{ }^{\circ} \mathrm{C}$ and methyl trifluorosulfonate $(9.9 \mathrm{mmol}, 1.09 \mathrm{~mL})$ was added. The resulting dark mixture was stirred overnight at ambient temperature. Purification of the crude product was performed by using column chromatography and $n$-hexane as initial eluent. The polarity of the eluent was increased by adding small portions of dichloromethane. Yield $1.23 \mathrm{~g}(88 \%)$, red crystals. Anal. Calcd. for $\mathrm{C}_{11} \mathrm{H}_{6} \mathrm{O}_{6} \mathrm{SW}$ (450.08): C: $29.35 \%$; H: 1.35 \%. Found: C: $29.11 \%$; H: $1.20 \% . \mathrm{Mp}: 102{ }^{\circ} \mathrm{C} . \mathrm{NMR}\left(\mathrm{CDCl}_{3}\right){ }^{1} \mathrm{H}: 8.17\left(\mathrm{dd}, J=4.0,1.1 \mathrm{~Hz}, 1 \mathrm{H}, \mathrm{H}_{\alpha}\right), 7.83(\mathrm{dd}, J=4.9,1.1$ $\left.\mathrm{Hz}, 1 \mathrm{H}, \mathrm{H}_{\gamma}\right), 7.23\left(\mathrm{dd}, J=5.0,4.1 \mathrm{~Hz}, 1 \mathrm{H}, \mathrm{H}_{\beta}\right), 4.68\left(\mathrm{~s}, 3 \mathrm{H}, \mathrm{CH}_{3}\right) .{ }^{13} \mathrm{C}\left\{{ }^{1} \mathrm{H}\right\}: 293.39\left(\mathrm{C}_{\text {carbene }}\right)$, $202.63\left(\mathrm{C}_{\text {trans }}\right), 197.80\left(\mathrm{C}_{\text {cis }}\right), 158.45\left(\mathrm{C}_{\mathrm{ipso}}\right), 141.90\left(\mathrm{C}_{\alpha}\right), 136.33\left(\mathrm{C}_{\mathrm{\gamma}}\right), 129.20\left(\mathrm{C}_{\beta}\right), 68.93\left(\mathrm{CH}_{3}\right)$. IR (dcm) v(cm $\left.{ }^{-1}\right): 2069$ (m), 1988 (w), 1963 (m), 1948 (vs). Suitable single crystals of 1 were obtained from a solution of $\mathbf{1}$ at ambient temperature. 


\subsection{Synthesis of 2}

2,5-Dibromothiophene ( $3.0 \mathrm{mmol}, 0.34 \mathrm{~mL})$ was added to $50 \mathrm{~mL}$ of thf, followed by a slow addition of ${ }^{n} \mathrm{BuLi}(7.0 \mathrm{mmol})$ at $-40{ }^{\circ} \mathrm{C}$. After $30 \mathrm{~min}$ of isothermal stirring, $\mathrm{W}(\mathrm{CO})_{6}(6.0 \mathrm{mmol}$, $2.11 \mathrm{~g}$ ) was added to the reaction mixture in a single portion. The resulting solution was stirred isotherm for an additional hour and then allowed to reach room temperature within $60 \mathrm{~min}$. Afterwards, solvent was changed dichloromethane and methyl trifluorosulfonate $(20.0 \mathrm{mmol}$, $2.41 \mathrm{~mL}$ ) was added at $-30{ }^{\circ} \mathrm{C}$ in a single portion. The dark mixture was removed from the cold bath and stirred overnight at ambient temperature. Purification of the crude product was performed by column chromatography and $n$-hexane as initial eluent. The polarity of the eluent was increased by adding small portions of dcm. Yield $1.51 \mathrm{~g}$ (55\%), purple solid. Anal. Calcd. for $\mathrm{C}_{18} \mathrm{H}_{8} \mathrm{O}_{12} \mathrm{SW}_{2}$ (816.05): C: $26.49 \%$; H: $0.99 \%$. Found: C: $29.43 \%$; $0.93 \%$. Mp: $264{ }^{\circ} \mathrm{C}$ (decomp.). NMR $\left(\mathrm{CDCl}_{3}\right){ }^{1} \mathrm{H}: 7.95$ (s, 2H, $\mathrm{H}_{\alpha}$ ), 4.67 (s, 6H, $\left.\mathrm{CH}_{3}\right) .{ }^{13} \mathrm{C}\left\{{ }^{1} \mathrm{H}\right\}: 296.50\left(\mathrm{C}_{\text {carbene }}\right.$ ), $202.64\left(\mathrm{C}_{\text {trans }}\right), 196.92\left(\mathrm{C}_{\text {cis }}\right), 162.53\left(\mathrm{C}_{\mathrm{ipso}}\right), 137.26\left(\mathrm{C}_{\alpha}\right), 69.09\left(\mathrm{CH}_{3}\right) . \mathrm{IR}(\mathrm{dcm}) v\left(\mathrm{~cm}^{-1}\right): 2062$ (m), $1974(w), 1948$ (vs), 1935 (s).

\subsection{Synthesis of 2,5-di-(1'-bromoferrocenyl)thiophene (3)}

$1,1^{\prime}$-Dibromoferrocene $(5.1 \mathrm{~g}, 14.8 \mathrm{mmol})$ was dissolved in $50 \mathrm{~mL}$ of thf and cooled to $-100{ }^{\circ} \mathrm{C}$.

${ }^{n} \mathrm{BuLi}(6 \mathrm{~mL}, 14.8 \mathrm{mmol})$ was slowly added and the reaction mixture left to stir at this temperature for $45 \mathrm{~min}$. Dry $\left[\mathrm{ZnCl}_{2} \cdot 2 \mathrm{thf}\right](4.2 \mathrm{~g}, 15.0 \mathrm{mmol})$ was added in a single portion and the resulting preparation was kept at $0^{\circ} \mathrm{C}$ for $30 \mathrm{~min}$. Afterward, 2,5-dibromothiophene $(0.83 \mathrm{~mL}$, $6.45 \mathrm{mmol})$ and $\left[\mathrm{Pd}\left(\mathrm{CH}_{2} \mathrm{CMe}_{2} \mathrm{P}^{\mathrm{t}} \mathrm{Bu}_{2}\right)(\mu-\mathrm{Cl})\right]_{2}(0.025 \mathrm{~g}, 36.4 \mu \mathrm{mol})$ were added to the solution. The reaction mixture was heated to $55^{\circ} \mathrm{C}$ and stirred for $36 \mathrm{~h}$ at this temperature. After cooling to ambient temperature, the crude product was adsorbed on alumina and purified by column 
chromatography on alumina, using a $n$-hexane/toluene mixture of ratio 4:1 (v:v) as eluent. Yield $1.60 \mathrm{~g}(43 \%)$, dark orange solid. Anal. Calcd. for $\mathrm{C}_{24} \mathrm{H}_{18} \mathrm{Br}_{2} \mathrm{Fe}_{2} \mathrm{~S}$ (609.98): C:47.24 \%; H:2.98 \%; Found: C:47.16 \%; H: $2.99 \% . \mathrm{Mp}: 220{ }^{\circ} \mathrm{C} . \mathrm{NMR}\left(\mathrm{CDCl}_{3}\right){ }^{1} \mathrm{H}: 6.90\left(\mathrm{~s}, 2 \mathrm{H}, \mathrm{Th}_{\alpha}\right), 4.98(\mathrm{~m}$, $\left.4 \mathrm{H}, \mathrm{H}_{\alpha}\right), 4.35\left(\mathrm{~m}, 4 \mathrm{H}, \mathrm{H}_{\beta}\right), 4.30\left(\mathrm{~m}, 4 \mathrm{H}, \mathrm{H}_{\alpha 2}\right), 4.06\left(\mathrm{~m}, 4 \mathrm{H}, \mathrm{H}_{\beta 2}\right) .{ }^{13} \mathrm{C}\left\{{ }^{1} \mathrm{H}\right\}: 139.49\left(\mathrm{Th}_{\mathrm{ipso}}\right), 123.42$ $\left(\mathrm{Th}_{\alpha}\right), 82.52\left(\mathrm{Fc}_{\mathrm{ipso} 2}\right), 78.97\left(\mathrm{Fc}_{\mathrm{ipso}}\right), 72.22\left(\mathrm{Fc}_{\alpha 2}\right), 71.28\left(\mathrm{Fc}_{\beta 2}\right), 69.23\left(\mathrm{Fc}_{\alpha}\right), 68.97\left(\mathrm{Fc}_{\beta}\right)$.

\subsection{Synthesis of $\mathbf{4}$ and $\mathbf{5}$}

Compound 3 (3.0 mmol, $0.34 \mathrm{~mL})$ was dissolved in $50 \mathrm{~mL}$ of thf and ${ }^{n} \mathrm{BuLi}(7 \mathrm{mmol})$ was slowly added at $-40{ }^{\circ} \mathrm{C}$. The reaction mixture was stirred isotherm for $30 \mathrm{~min}$ after which $\mathrm{W}(\mathrm{CO})_{6}(6.0 \mathrm{mmol}, 2.11 \mathrm{~g})$ was added in a single portion. The solution was kept at $-40{ }^{\circ} \mathrm{C}$ for 1 $\mathrm{h}$ and then allowed to reach ambient temperature within $60 \mathrm{~min}$. All volatiles were removed and the residue was redissolved in $\mathrm{dcm}$. Methyl trifluorosulfonate $(20.0 \mathrm{mmol}, 2.41 \mathrm{~mL})$ was added at $-30^{\circ} \mathrm{C}$ after which the solution darkened. The mixture was removed from the cold bath and stirred overnight at room temperature. Purification of the product was performed by using column chromatography and $n$-hexane as initial eluent. The polarity of the eluent was increased by adding small portions of $\mathrm{CH}_{2} \mathrm{Cl}_{2}$. Compound 4 eluted first as a dark-red fraction followed by compound $\mathbf{5}$ (brown-red).

Compound 4: Yield 0.96 g (40\%), red brown crystals. Anal. Calcd. for $\mathrm{C}_{31} \mathrm{H}_{22} \mathrm{Fe}_{2} \mathrm{O}_{6} \mathrm{SW}$ (818.1): C, $45.51 \%$; H, $2.72 \%$; found C, $45.59 \%$; H, $2.79 \% . \mathrm{Mp}: 237{ }^{\circ} \mathrm{C}$ (decomp.). NMR $\left(\mathrm{CDCl}_{3}\right){ }^{1} \mathrm{H}: 6.83(\mathrm{~m}, 2 \mathrm{H}, \mathrm{Th}), 4.93\left(\mathrm{~m}, 2 \mathrm{H}, \mathrm{H}_{\alpha 3}\right), 4.74\left(\mathrm{~m}, 2 \mathrm{H}, \mathrm{H}_{\beta 3}\right), 4.66\left(\mathrm{~m}, 2 \mathrm{H}, \mathrm{H}_{\alpha 2}\right), 4.58(\mathrm{~m}$, $\left.2 \mathrm{H}, \mathbf{H}_{\beta 2}\right), 4.39\left(\mathrm{~m}, 2 \mathrm{H}, \mathbf{H}_{\alpha}\right), 4.35\left(\mathrm{~s}, 3 \mathrm{H}, \mathrm{CH}_{3}\right), 4.31\left(\mathrm{~m}, 2 \mathrm{H}, \mathbf{H}_{\beta}\right), 4.14(\mathrm{~s}, 5 \mathrm{H}, \mathrm{Cp}) .{ }^{13} \mathrm{C}\left\{{ }^{1} \mathrm{H}\right\}:$ $307.75\left(\mathbf{C}_{\text {carbene }}\right), \quad 202.59\left(\mathbf{C}_{\text {trans }}\right), \quad 198.18 \quad\left(\mathbf{C}_{\text {cis }}\right), \quad 142.40 \quad\left(\mathrm{Th}_{\text {ipso }}\right), 137.54\left(\mathrm{Th}_{\alpha}{ }^{\prime}\right), 96.18$ $\left(\mathrm{Fc}_{\text {ipso3 }}\right), 83.77\left(\mathrm{Fc}_{\mathrm{ipso} 2}\right), 80.07\left(\mathrm{Fc}_{\mathrm{ipso}}\right), 77.36\left(\mathbf{C}_{\alpha 3}\right), 76.92\left(\mathbf{C}_{\beta 3}\right), 74.85\left(\mathbf{C}_{\alpha 2}\right), 71.20\left(\mathbf{C}_{\beta 2}\right), 70.15$ 
$\left(\mathbf{C}_{\alpha}\right), 68.93\left(\mathbf{C H}_{3}\right), 68.67\left(\mathbf{C}_{\beta}\right), 66.83(\mathrm{Cp})$. IR $(\mathrm{dcm}) v\left(\mathrm{~cm}^{-1}\right)$ : $2062(\mathrm{~m}), 1971(\mathrm{w}), 1929$ (vs, br).

Suitable single crystals of $\mathbf{4}$ were obtained from a solution of $\mathbf{4}$ at ambient temperature.

Compound 5: Yield $0.99 \mathrm{~g}$ (30 \%), dark brown crystals. Anal. Calcd. for $\mathrm{C}_{38} \mathrm{H}_{24} \mathrm{Fe}_{2} \mathrm{O}_{12} \mathrm{SW}_{2}$ (1184.0): C, $38.54 \%$; H, $2.05 \%$; found C, $38.57 \%$; H, $2.06 \%$. Mp: $248{ }^{\circ} \mathrm{C}$ (decomp.). NMR $\left(\mathrm{CDCl}_{3}\right){ }^{1} \mathrm{H}: 6.85\left(\mathrm{~s}, 2 \mathrm{H}, \mathrm{Th}_{\alpha}\right), 4.93\left(\mathrm{~m}, 4 \mathrm{H}, \mathbf{H}_{\alpha 2}\right), 4.72\left(\mathrm{~m}, 4 \mathrm{H}, \mathbf{H}_{82}\right), 4.67\left(\mathrm{~m}, 4 \mathrm{H}, \mathbf{H}_{\alpha}\right), 4.40(\mathrm{~m}$, $\left.4 \mathrm{H}, \mathbf{H}_{\beta}\right), 4.32\left(\mathrm{~s}, 6 \mathrm{H}, \mathbf{C H}_{3}\right) \cdot{ }^{13} \mathrm{C}\left\{{ }^{1} \mathrm{H}\right\}: 308.47\left(\mathbf{C}_{\text {carbene }}\right), 202.42\left(\mathbf{C}_{\text {trans }}\right), 198.14\left(\mathbf{C}_{\text {cis }}\right), 139.16$ $\left(\mathrm{Th}_{\mathrm{ipso}}\right), 123.97\left(\mathrm{Th}_{\alpha}\right), 96.15\left(\mathrm{Fc}_{\mathrm{ipso2}}\right), 82.99\left(\mathrm{Fc}_{\mathrm{ipso}}\right), 77.34\left(\mathrm{C}_{\alpha 2}\right), 76.86\left(\mathrm{C}_{\mathrm{B2}}\right), 74.78\left(\mathrm{C}_{\alpha}\right), 71.65$ $\left(\mathrm{C}_{B}\right), 68.68\left(\mathrm{CH}_{3}\right)$. IR (dcm) v( $\left.\mathrm{cm}^{-1}\right): 2060(\mathrm{~m}), 1972(\mathrm{w}), 1929$ (vs, br). Suitable single crystals of $\mathbf{5}$ were obtained from a solution of $\mathbf{5}$ at ambient temperature.

\subsection{Electrochemistry}

The electrochemical measurements were carried out under an argon atmosphere on $1.0 \mathrm{mmol} \cdot \mathrm{L}^{-1}$ dichloromethane solutions containing $0.1 \mathrm{~mol} \cdot \mathrm{L}^{-1}$ of $\left[\mathrm{N}^{n} \mathrm{Bu}_{4}\right]\left[\mathrm{B}\left(\mathrm{C}_{6} \mathrm{~F}_{5}\right)_{4}\right]$ as supporting electrolyte utilizing a Voltalab 10 electrochemical laboratory from Radiometer analytical [29]. An OTTLE cell placed in a Varian Cary 5000 UV-VIS/NIR absorption spectrometer or in a Thermo Nicolet 200 FT-IR spectrometer was used in spectroelectrochemical measurements [14]. For voltammetry, a three electrode cell with a platinum wire counter electrode, a glassy carbon working electrode and a $\mathrm{Ag} / \mathrm{Ag}^{+}$reference electrode was used. The working electrode was prepared by polishing with a Buehler micro cloth using Buehler diamond pastes with decreasing sizes ( 1 to $0.25 \mu \mathrm{m}$ ). The $\mathrm{Ag} / \mathrm{Ag}^{+}$reference electrode was constructed from a silver wire inserted into a luggin capillary with a vycor tip containing a solution of $0.01 \mathrm{~mol} \cdot \mathrm{L}^{-1} \mathrm{AgNO}_{3}$ as well as $0.1 \mathrm{~mol} \cdot \mathrm{L}^{-1}\left[\mathrm{~N}^{n} \mathrm{Bu} 4\right]\left[\mathrm{B}\left(\mathrm{C}_{6} \mathrm{~F}_{5}\right)_{4}\right]$ in acetonitrile. This luggin capillary was inserted into a second luggin capillary with vycor tip filled with a $0.1 \mathrm{~mol} \cdot \mathrm{L}^{-1}\left[\mathrm{~N}^{n} \mathrm{Bu}_{4}\right]\left[\mathrm{B}\left(\mathrm{C}_{6} \mathrm{~F}_{5}\right)_{4}\right]$ solution in 
dichloromethane. Cyclic voltammetry was carried out using a scan rate of $100 \mathrm{mVs}^{-1}$. If irreversible redox processes were investigated, a scan rate of $300 \mathrm{mVs}^{-1}$ was also applied. Successive experiments under the same experimental conditions showed that all formal reduction and oxidation potentials were reproducible within $5 \mathrm{mV}$. Experimentally potentials were referenced against a $\mathrm{Ag} / \mathrm{Ag}^{+}$reference electrode but the results are presented referenced against the $\mathrm{FcH} / \mathrm{FcH}^{+}$couple $\left(E^{0,}=0.0 \mathrm{mV}\right)$ as required by IUPAC [30]. When decamethylferrocene was used as an internal standard, the experimentally measured potential was converted in to $E v s$ $\mathrm{FcH} / \mathrm{FcH}^{+}$by addition of $-0.61 \mathrm{~V}[31]$. Cyclic voltammograms were taken after typical two scans and are considered to be steady state cyclic voltammograms, in which the signal pattern differs not from the initial sweep. Finally, the experimental data were processed on Microsoft Excel worksheets.

\subsection{Single-Crystal X-ray Diffraction Analysis}

Data were collected with an Oxford Gemini S diffractometer at $100 \mathrm{~K}$ using Mo K $\alpha(\lambda=0.71073$ Å) radiation. The structures were solved by direct methods using SHELXS-97 and refined by full matrix least-square procedures on $\mathrm{F}^{2}$ using SHELXL-97 [32]. All non-hydrogen atoms were refined anisotropically and a riding model was employed in the refinement of the hydrogen atom positions.

\section{Acknowledgements}

This work is supported by the National Research Foundation, South Africa, (DIB, Grant number 76226; JCS, Grant number 81829), and by the Spanish MICINN and CAM (IF, Grants CTQ2010-20714-CO2-01/BQU, Consolider-Ingenio 2010, CSD2007-00006, S2009/PPQ-1634). 


\section{Appendix A. Supplementary material}

The UV-Vis-NIR spectra of $\mathbf{2 , 4}$ and $\mathbf{5}$ in dichloromethane as well as a table of crystal data (see Table S-1) are available as supplementary material for this paper. Crystallographic data (see Table S-1, excluding structure factors) for the structures in this paper have been deposited with the Cambridge Crystallographic Data Centre, CCDC, 12 Union Road, Cambridge CB21EZ, UK. Copies of the data can be obtained free of charge on quoting the depository numbers CCDC969409 (1), $969408 \quad$ (4) and $969407 \quad$ (5) (Fax: +44-1223-336-033; e-mail: deposit@ccdc.cam.ac.uk, http://www.ccdc.cam.ac.uk).

\section{References}

[1] (a) Bezuidenhout, D. I.; Lotz, S.; Liles,D. C.; van der Westhuizen, B. Coord. Chem. Rev., 2012, 51, 479-524; (b) Astruc, D. Electron Transfer and Radical Processes in Transition Metal Chemistry, VCH, New York, 1995; (c) Astruc, D. Acc. Chem. Res., 1997, 30, 383-391; (d) Long, N. J. Angew. Chem. Int. Ed. Engl., 1995, 34, 21-38; (e) Behrens, U.; Brussaard, H.; Hagenau, U.; Heck, J.; Hendrickx, E.; Kornich, J.; van der Linden, J. G. M.; Persoons, A.; Spek, A. L.; Veldman, N.; Voss, B.; Wong, H. Chem. Eur. J.,1996, 2, 98-103.

[2] ( a) Watanuki, S.; Ochifuji, N.; Mori, M.; Organometallics, 1995, 14, 5062-5067; (b) Fernández-Rodríguez, M. A.; García-García, P.; Aquilar, E. Chem. Commun., 2010, 46, 76707687.

[3] Bezuidenhout, D. I.; van der Watt, E.; Liles, D. C.; Landman, M.; Lotz, S. Organometallics, 2008, 27(11), 2447-2456. 
[4] (a) Lage, M. L.; Curiel, D.; Fernández, I.; Mancheño, M. J.; Gómez-Gallego, M.; Molina, P.; Sierra, M. A. Organometallics, 2011, 30, 1794-1803; (b) Limberg, A.; Amélia, M.; Lemos, N. D. A.; Pombeiro, A. J. L. Port. Electrochim. Acta., 1995, 13, 319-323; (c) Crause, C.; Görls, H.; Lotz, S.; Dalton Trans., 2005, 1649-1657; (d) Terblans, Y. M.; Roos, H. M.; Lotz, S. J. Organomet. Chem., 1998, 566, 133-142.

[5] (a) van der Westhuizen, B; Speck, J. M.; Korb, M.; Friedrich, J.; Bezuidenhout, D. I.; Lang, H. Inorg. Chem. 2013, 52, 14255-14264; (b) Bezuidenhout, D. I.; Fernández, I.; van der Westhuizen, B.; Swarts, P. J.; Swarts, J. C. Organometallics, 2013, 32(24), 7334-7344.

[6] Fischer, E. O.; Held, W.; Kreissl, F. R.; Frank, A.; Huttner, G. Chem. Ber. 1977, 110, 656666 ;

[7] Landman, M.; Pretorius, R.; Buitendach, B. E.; van Rooyen, P. H., Conradie, J. Organometallics, 2013, 32, 5491-5503.

[8] Dong, T. Y.; Chang, C. K.; Lee, S. H.; Lai, L. L.; Chiang, M. Y. N.; Lin, K. L. Organometallics, 1997, 16, 5816-5825.

[9] Negishi, E. L., King, A. O., Okukado, N. J. Org. Chem. 1977, 42, 1821-1823.

[10] (a) Clark, H. C., Goel, A. B., Goel, R. G., Goel, S., Ogini, W. O., Inorg. Chim. Acta, 1978, 31, L441-L442; (b) Goel, A. B. Goel, S., Inorg. Chim. Acta 1985, 98, 67-70.

[11] Pickett, T. E., Richards, C. J., Tetrahedron Lett., 1999, 40, 5251-5254.

[12] (a) Braterman, P. S. Metal Carbonyl Spectra; Academic Press Inc.: London, U.K., 1975, 68; (b) Adams, D. M. Metal-Ligand and Related Vibrations; Edward Arnold Publishers Ltd: London, U.K., 1967, 98.

[13] McIver, J. W.; Komornicki, A. K. J. Am. Chem. Soc., 1972, 94, 2625-2633.

[14] Krejčik, M.; Daněk, M.; Hartl, F. J. Electroanal. Chem. 1991, 317, 179-187. 
[15] A higher reversibility in reduction events has its origin probably in the ability of $\mathbf{2}$ to stabilize negative charge better than $\mathbf{1}$ or other more electron-rich Fischer carbene complexes in the corresponding redox active states (see ref. Error! Bookmark not defined. and Error! Bookmark not defined.).

[16] Speck, J.M., Claus, R., Hildebrandt, A., Rüffer, T., Erasmus, E., van As, L., Swarts, J.C., Lang, H., Organometallics, 2012, 31, 6373-6380.

[17] The partial reversibility is shown inter alia in the $i_{p d} / i_{p c}$ ratio and the occurrence of follow up reactions during the carbene reductions, e.g. the oxidation process around $75 \mathrm{mV}$ in Fig. S-1.

[18] (a) Kissinger, P. T.; Heineman, W. R. J. Chem. Educ. 1983, 60, 702-706; (b) Mabbott, G. A. J. Chem. Educ. 1983, 60, 697-702.

[19] (a) Barlow, S. Inorg. Chem. 2001, 40, 7047-7053; (b) Demadis, K. D.; Hartshorn, C. M.; Meyer, T. J. Chem. Rev. 2001, 101, 2655-2686; (c) D'Alessandro, D. M.; Keene, F. R. Chem. Soc. Rev. 2006, 35, 424-440.

[20] Baldoli, C.; Cerea, P.; Falciola, L.; Giannini, C.; Licandro, E.; Maiorana, S.; Mussini, P.; Perdicchia, D. J. Organomet. Chem. 2005, 690, 5777-5787.

[21] (a) Connor, J. A.; Lloyd, J. P. J. Chem. Soc., Dalton Trans. 1972, 1470-1476; (b) Rosenblum, M.; Santer, J. O.; Howells, W. G. J. Am. Chem. Soc. 1963, 85, 1450-1458; (c) Sohn, Y. S.; Hendrickson, D. N.; Gray, H. B. J. Am. Chem. Soc. 1971, 93, 3603-3612.

[22] Zhu, Y.; Wolf, M. O. J. Am. Chem. Soc. 2000, 122, 10121-10125.

[23] (a) Hildebrandt, A.; Rüffer, T.; Erasmus, E.; Swarts, J. C.; Lang, H. Organometallics, 2010, 29, 4900-4905; (b) Hildebrandt, A.; Schaarschmidt, D.; Lang, H. Organometallics, 2011, 30, 556-563; (c) Speck, J. M.; Schaarschmidt, D.; Lang, H. Organometallics 2012, 31, 1975-1982;

(d) Hildebrandt, A.; Lehrich, S. W.; Schaarschmidt, D.; Jaeschke, R.; Schreiter, K.; Spange, S.; 
Lang, H. Eur. J. Inorg. Chem. 2012, 1114-1121; (e) Taher, D.; Awwadi, F. F.; Pfaff, U.; Speck, J. M.; Rüffer, T.; Lang, H. J. Organomet. Chem. 2013, 736, 9-18; (f) Hildebrandt, A.; Lang, H. Dalton Trans. 2011, 40, 11831-11837; (g) Miesel, D.; Hildebrandt, A.; Korb, M.; Low, P. J.;

Lang, H. Organometallics 2013, 32, 2993-3002.

[24] Robin, M. B.; Day, P. Adv. Inorg. Chem. Radiochem. 1968, 10, 247-422.

[25] Interconfigurational (IC) transition.

[26] (a) Warratz, R.; Aboulfadl, H.; Bally, T.; Tuczek, F. Chem. Eur. J. 2009, 15, 1604-1617; (b) Warratz, R.; Tuczek, F. Inorg. Chem. 2009, 48, 3591-3607.

[27] (a) Breuer, R.; Schmittel, M. Organometallics 2013, 32, 5980-5987; (b) Cowan, D. O.; Kaufman, F. J. Am. Chem. Soc. 1970, 92, 6198-6204; (c) Levanda, C.; Bechgaard, K.; Cowan, D. O. J. Org. Chem. 1976, 41, 2700-2704.

[28] (a) Atwood, C. G.; Geiger, W. E. J. Am. Chem. Soc. 1994, 116, 10849-10850; (b) Lohan, M.; Ecorchard, P.; Rüffer, T.; Justaud, F.; Lapinte, C.; Lang, H. Organometallics 2009, 28, 1878-1890; (c) Paul, F.; Toupet, L.; Thépot, J.-Y.; Costuas, K.; Halet, J.-F.; Lapinte, C. Organometallics 2005, 24, 5464-5478.

[29] (a) LeSuer, R. J.; Buttolph, C.; Geiger, W. E. Anal. Chem. 2004, 76, 6395-6401; (b) Barrière, F.; Camire, N.; Geiger, W. E.; Mueller-Westerhoff, U. T.; Sanders, R. J. Am. Chem. Soc. 2002, 124, 7262-7263; (c) Barrière, F.; Geiger, W. E. J. Am. Chem. Soc. 2006, 128, 39803989.

[30] Gritzner, G.; Kuta, J. Pure Appl. Chem. 1984, 56, 461-466.

[31] Nafady, A.; Geiger, W. E. Organometallics 2008, 27, 5624-5631. 
[32] (a) Sheldrick, G. M. Acta Crystallogr., Sect. A 1990, 46, 467; (b) Sheldrick, G. M. SHELXL-97, Program for Crystal Structure Refinement; Universität Göttingen, Göttingen, Germany, 1997. 